\title{
Educational Technology: A Review of the Integration, Resources, and Effectiveness of Technology in K-12 Classrooms
}

\author{
Adolph J. Delgado, Liane Wardlow, Katherine McKnight, and \\ Kimberly O'Malley \\ Research \& Innovation Network, Pearson, USA
}

\author{
adolph.delgado@pearson.com liane.wardlow@pearson.com \\ kathy.mcknight@pearson.com kimberly.omalley@pearson.com
}

\begin{abstract}
There is no questioning that the way people live, interact, communicate, and conduct business is undergoing a profound, rapid change. This change is often referred to as the "digital revolution," which is the advancement of technology from analog, electronic and mechanical tools to the digital tools available today. Moreover, technology has begun to change education, affecting how students acquire the skill sets needed to prepare for college and a career and how educators integrate digital technological instructional strategies to teach. Numerous studies have been published discussing the barriers of integrating technology, the estimated amount of investment that is needed in order to fully support educational technology, and, of course, the effectiveness of technology in the classroom. As such, this article presents a critical review of the transitions that technology integration has made over the years; the amount of resources and funding that has been allocated to immerse school with technology; and the conflicting results presented on effectiveness of using is technology in education. Through synthesis of selected themes, we found a plethora of technological instructional strategies being used to integrate technology into K-12 classrooms. Also, though there have been large investments made to integrate technology into K12 classrooms to equip students with the skills needed to prepare for college and a career, the practical use of this investment has not been impressive. Lastly, several meta-analyses showed promising results of effectiveness of technology in the classroom. However, several inherent methodological and study design issues dampen the amount of variance that technology accounts for.
\end{abstract}

Keywords: K-12, digital learning, devices, one-to-one, technology, literature review

Material published as part of this publication, either on-line or in print, is copyrighted by the Informing Science Institute. Permission to make digital or paper copy of part or all of these works for personal or classroom use is granted without fee provided that the copies are not made or distributed for profit or commercial advantage AND that copies 1) bear this notice in full and 2) give the full citation on the first page. It is permissible to abstract these works so long as credit is given. To copy in all other cases or to republish or to post on a server or to redistribute to lists requires specific permission and payment of a fee. Contact Publisher@InformingScience.org to request redistribution permission.

\section{Introduction}

The digital revolution has changed the way that people obtain information. There is more information than any one person could ever acquire available at one's fingertips via the Internet. Although disparities in technology access still exist today, the vast majority of students in the United States are able to 
access the Internet from home or school (Pearson, 2013; Madden, 2013; Project Tomorrow, 2014; Information Capsule Research Services, 2014), meaning that most students have access to vast amounts of information. However, having information easily available has its caveats; for example, not all of the information available on the Internet is reliable and accurate. Hence, technology has not only affected the amount information available to students, but it has also transitioned the types of skills students need to identify quality information and where learning takes place.

In 2009, the Common Core State Standards were established to create standards and guidelines for schools to follow in order to build skills, such as critical thinking skills, that will help students perform well in college/university or make them competitive for a career (ASCD, 2009; ODEP, 2009). To assist in facilitating these standards, educators are incorporating using technological tools in their curriculum and have extended learning outside of the classroom into online environments.

Educators have used technology to teach since the 1920s, when film and radios were introduced into classrooms (Cuban, 1993). However, it was not until the 1980s and 1990s that school reforms began utilizing computers to assist in teaching students and to individualize learning $(\mathrm{Cu}-$ ban, 1993). Computer teaching programs traditionally focused on facilitating lower-level cognitive skills through the rote memorization of facts and figures (Flick \& Bell, 2000), but advents in technology and gaming have been shown to be efficient tools to build higher-level cognitive skills, such as critical thinking skills (Jonassen, 2000).

Studies have suggested that online environments can be very beneficial. For example, integrating the course tool WebCT has been shown to improve reading engagement and critical thinking skills (Burgess, 2009). Additionally, in a study by Morin, Thomas, and Saadé (2012), students perceived that using the Web contributed the most to fostering critical thinking skills. Further, online courses allow students with the opportunity to master their learning, learn at their own pace, and engage anonymously in online discussions (Saadé, Morin, \& Thomas, 2012).

Learning outside of the classroom has also been made possible because of technology. Students are no longer limited to face-to-face learning, since technological advancements have made it possible for students to choose whether they want to attend class either face-to-face or via online or both. With the significant increase in Internet access and computers in and out of classrooms (Gray, Thomas, \& Lewis, 2010), there are numerous options for learning to take place in out of the classroom. The most popular learning environments include: Bring Your Own Device (BYOD); Blended Learning, also known as hybrid courses; Flipped Learning and Flipped Classrooms; and Online Learning, also known as distance education. Each environment differs in the proportion of time spent learning in the classroom to the time spent learning online. This variety of classroom formats allows students to take courses that are not available at their school. Some online learning courses have helped meet the needs of specific groups of students. These formats further offer students the option of taking advanced or college level courses. Lastly, in some cases, schools have permitted students who failed a course to retake it via online for credit (e.g., credit recovery).

The research on the effects of technology in the classroom is increasing rapidly, but there seems to be much debate on whether or not technology has been making a significant impact on student achievement. Based on what we know, technology in the classroom is definitely being utilized to help students strengthen a certain set of skills needed to be successful in the 21 st century. Also, technology is allowing students to learn both in and outside of a brick and mortar classroom. Although these are only two key reasons, out of many other reasons, to embrace using technology in the classroom, understanding the facets and logistics surrounding this method of teaching is equally, if not more, critical. Therefore, in conducting this literature review, we aimed to answer three key questions: 
1. How is technology currently being integrated into schools?

2. What investments have been made to support educational technology? How does investments increase technology integration and use in schools?

3. How effective is educational technology?

The catalyst for the first question stemmed from a prominent study conducted by Hew and Brush (2007), in which a total of 123 technology integration barriers were identified in previous empirical studies. Hew and Brush systematical investigated the previous literature and concluded that there were 6 main categories that limited and hindered technology integration: (a) resources, (b) knowledge and skills, (c) institution, (d) attitudes and beliefs, (e) assessment, and (f) subject culture.

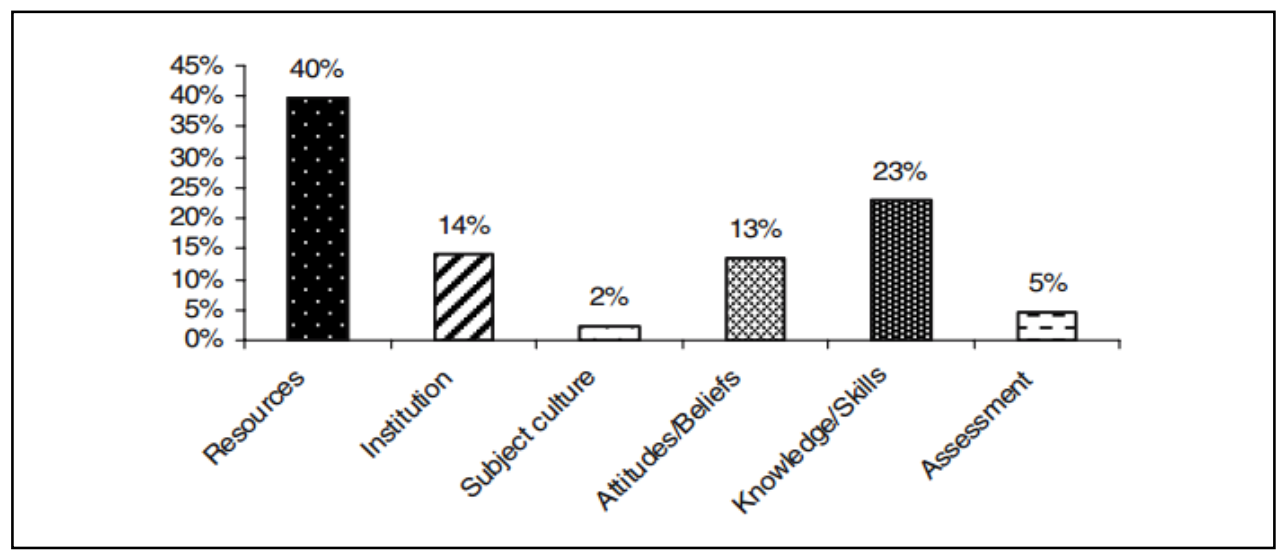

Figure 1: Barriers of integration

Source: Hew and Brush (2007)

Of the six barriers, $49(40 \%)$ of the articles indicated that resources were the primary barrier of technology integration. The authors described resources as having "one or more of the following: technology, access to available technology, time, and technical support. Lack of technology includes insufficient computers, peripherals, and software" (p. 226). Hew and Brush argued that "Without adequate hardware and software, there is little opportunity for teachers to integrate technology into the curriculum" (p. 226). Even if technology is abundant, teachers may still not have access to these resources. As noted by Fabry and Higgs in 1997, "Access to technology is more than merely the availability of technology in a school; it involves providing the proper amount and right types of technology in locations where teachers and students can use them" (as cited in Hew \& Brush, 2007, p. 226).

Strategies that Hew and Brush (2007, p. 233) suggested to obtain this resource were to: 1) Introduce technology into one or two subject areas at a time to ensure that teachers and students in those areas have adequate technology and access to technology; 2) Create a hybrid technology setup in classrooms that involved cheaper computer systems; and 3) Use laptops with wireless connections to save building and maintenance costs of the computer laboratories.

The purpose of second question stems is to understand the amount of investment that has been made to support educational technology. More specifically, what investment have been made to accommodate the recent transition in standards and guidelines in education to build skills that will help students perform well in college/university or make them competitive for a career. Unfortunately, as noted, even if technology is made available, teachers may still not have access to them. Thus, the follow up question is posed to understand how these investments increase technology integration and access in schools. 
The last question is a question that has been a topic of numerous debates. Numerous studies and several meta-analyses have been conducted in order to answer this question. However, there have been some inherent issues that have risen in the process. For example, the term "educational technology" is a generic and ambiguous term that has been used to reference computer-assisted instruction (CAI), simulations, games, or laboratory instruments, or technology software/hardware. Another issue is how to measure effectiveness. Some studies measure the effectiveness of the tool while others measure the effectiveness of knowledge gained. Our research question aims to amalgamate the most prominent research and meta-analyses and report the overall impact educational technology across different methodologies.

\section{Method}

\section{Article Selection}

Articles that were selected for this literature review span from 1986 to 2014. The literature primarily focuses on technology use in education; outcomes of technology in the classroom; and online learning environments. The purpose of selecting these key themes was to convey how technology integration has changed across the years; accurately report the amount of resources and funding that has been allocated to immerse school with technology; and what has the scientific community found in regard to the effectiveness of using is technology in education.

WorldCat and Google Scholar were the two databases used to search for articles related to technology in education. The articles were selected and identified by primarily using the search terms or keywords 'technology,' 'education,' 'classroom immersion,' 'one-to-one computing,' 'K-12,' 'online learning' and 'digital learning.' Hundreds of abstracts were investigated but, ironically, only a few provided relevant information that would enable this literature review to accurately answer our three key questions. Ninety articles were selected to be used in this manuscript. Of those 90 selected, $27 \%$ contained the word 'technology,' followed by $27 \%$ for 'education,' $10 \%$ for 'K-12.' $8 \%$ for 'online learning/education environment,' $2 \%$ for 'one-to-one computing,' and $1 \%$ for 'digital learning' and $0 \%$ for 'classroom immersion.' Other articles related technology immersion, effectiveness, integration, critical thinking, and common core standards were included in the literature review, though none of the said keywords were mentioned in their titles.

\section{Initial Screening}

A simple search using Google Scholar with the keywords 'technology in education,' yielded approximately 89,900 citations with those words in the title. The abstracts, method sections, and results of the articles selected were investigated to make certain that each manuscript had the information to convey an accurate picture of how technology integration has changed across the years; accurately report the amount of resources and funding that has been allocated to immerse school with technology; and what has the scientific community found in regard to the effectiveness of using is technology in education. For consistency, the term 'technology' was used to represent any digital device, operating system, or technological software/hardware to can be used to perform or facilitate an objective.

\section{Full-Text Screening}

Approximately $90 \%$ of the articles selected mentioned using technology to teach. Seventeen meta-analyses were also selected to report the effect sizes of previous findings on the effectiveness of educational technology. Five national surveys/reports were further included to convey the most recent reported amount of digital tools and which type of digital are being used by teachers. For consistency, articles written about critical thinking skills were also included to bolster the need to use technology to help students build 21 st century skills. 


\section{Findings}

\section{(RQ1) Technology Integration}

There are several distinct ways technology can be integrated into classrooms to create a technologically enhanced learning environment. Many of these environments advance pedagogy (and andragogy) and some even go so far as to restructure core functions of classrooms (Moeller \& Reitzes, 2011; Hopson, Simms, \& Knezek, 2002; Muir-Herzig, 2004; McKnight et al., in press) But as with any model or program, access is critical to success. One of the biggest changes occurring in the digital age is the movement to increase access. This transition is from a model that has one (or very few) computer(s) in classrooms, which makes integrating e-learning activities difficult, to a model that strives to get one computer (or other e-learning digital device) into the hands of every student every day. A 1:1 computing environment holds great promise for creating efficient learning, especially because it means more hands on time with technology for each student (Bebell, 2005; Bebell \& Kay, 2010; Bebell \& O'Dwyer, 2010). (The term '1:1' refers to the ratio of technology devices to students, e.g., one laptop or mobile device per student.) After all, classroom technology cannot create a measurable impact on student learning if students do not have access to the technology in the first place (Norris, Sullivan, Poirot, \& Soloway; 2008; Bebell \& Kay, 2010). Additionally, teachers cannot be expected to transform their instructional methods if only a few of their students have access to digital devices at a time. Currently, the reported ratio of students-to-devices has been reduced from 11:1 to 1.7:1 (Gray, Thomas, \& Lewis, 2010).

Schools with higher ratios of students per device likely reflect limited resources to purchase the hardware, software, and infrastructure for more devices rather than a belief that having multiple students per device is preferable to a 1:1 ratio. Some schools and districts have been able to reduce the ratio of devices to students down to $1: 1$, which is often thought to be the best-case scenario.

\section{Instructional strategies}

As we enter the digital age, equipping students with technology is crucial. As noted, teachers and administrators must decide on the best ways to integrate technology into curriculum and instruction. One method is for schools and/or districts to purchase the hardware, software, insurance and infrastructure throughout their classrooms for their students. An advantage to this approach is that there are often cost savings when purchases are bundled. Additionally, such an approach often results in students and teachers working with the same digital devices, which addresses concerns of equality, security, and access. However, because many districts are currently coping with significant budget shortfalls, purchases of devices, and maintenance of those devices, for all students in a school or district is sometimes not feasible. As such, there is wide spectrum of technology environments that can deliver educational content. Depending on the needs of the students and the resources of the schools/districts, classrooms could be web facilitated, fully online, or could fall in the middle of the spectrum via blended learning (Table 1). 
Table 1: Technology course description

\begin{tabular}{|c|c|l|}
\hline $\begin{array}{c}\text { Proportion } \\
\text { of Content }\end{array}$ & $\begin{array}{c}\text { Type of } \\
\text { Course }\end{array}$ & \multicolumn{1}{c|}{ Typical Description } \\
\hline $0 \%$ & Traditional & $\begin{array}{l}\text { Course where no online technology used - content is delivered } \\
\text { in writing or orally }\end{array}$ \\
\hline 1 to $29 \%$ & Web Facilitated & $\begin{array}{l}\text { Course that uses web-based technology to facilitate what is es- } \\
\text { sentially face-to-face course. May use a course management } \\
\text { system (CMS) or web pages to post the syllabus and assign- } \\
\text { ments. }\end{array}$ \\
\hline 30 to $37 \%$ & Blended/Hybrid & $\begin{array}{l}\text { Course that blends online and face-to-face delivery. Substantial } \\
\text { proportion of the content is delivered online, typically uses } \\
\text { online discussions, and typically has a reduced number of face- } \\
\text { to-face meetings. }\end{array}$ \\
\hline $80+\%$ & Online & $\begin{array}{l}\text { A course where most or all of the content is delivered online. } \\
\text { Typically have no face-to-face meetings. }\end{array}$ \\
\hline
\end{tabular}

Source: I. E. Allen and Seaman (2011)

\section{Bring your own device (BYOD)}

The idea behind BYOD is simple, though implementation can be complicated. In a BYOD environment, every student brings a personally owned digital device to school to use for academic purposes (Grant \& Barbour, 2013). BYOD environments are possible in part because the costs of digital devices are low enough that many families have at least one device. One advantage of a BYOD program is the reduced cost to the school district. After all, if students are able to supply their own devices, at minimum that reduces the hardware and insurance costs to the school. Another advantage is that students are able to use technology that they are not only already familiar with but that they also have access to at home for homework (Ally \& Tsinakos, 2014). A disadvantage is that students will likely have different types of devices with different capabilities (Ally $\&$ Tsinakos, 2014). This adds a layer of logistical support with which schools, districts and teachers must cope. This is not a minor or uncomplicated issue with easy answers. Currently, schools and districts are finding and developing solutions, which may serve to inform other stakeholders who adopt a BYOD program in the future.

\section{Blended learning}

Blended learning, also known as hybrid, refers to an educational environment where teachers use digital technology in traditional or flipped classrooms on a regular basis. That is, blended classrooms utilize both device-driven instruction and face-to-face instruction. The objective is to overcome the weaknesses associated with fully online instruction, such as isolation (Islam, 2002), while taking advantage of the benefits associated with technology-driven instruction such as increased achievement of learning objectives (Singh \& Reed, 2001; Lim, Morris, \& Kupritz, 2014; Rosen \& Beck-Hill, 2012). There are many choices and variables involved in determining the structure of a blended classroom. The decisions regarding that structure should be made with respect to the objectives and capabilities of the instructor, the students, and the environment (McGee \& Reis, 2012).

Evidence of the efficacy of blended learning is moderate, yet promising (Vignare, 2007). Findings from studies on online environments show mixed results; however, findings from metaanalyses show that online courses are at least as effective as traditional classrooms (c.f., Russell, 1999; Zhao, Lei, Yan, Lai, \& Tan, 2005). Zhao et al.'s (2005) meta-analysis found no significant 
differences between blended learning and traditional classrooms; they did, however, report that blended learning could be better than traditional classrooms, when instructors' involvement, interaction, content, student capabilities, and the right amount of human to technology were combined. A more recent meta-analysis by Means, Toyama, Murphy, Bakia, and Jones (2009) found promising results. Forty-six studies comparing online and face-to-face conditions, yielded sufficient data to produce 51 effect sizes. Eleven of the 51 effect sizes supported blended learning over traditional face-to-face conditions. As the digital revolution gains momentum, providing increasing opportunities for blended learning options, the number of enrollments into hybrid classrooms will become fluid. Also, with the research bolstering the potential of blended learning, policy support will continue to transform the education system.

\section{Flipped learning and flipped classrooms}

Flipped learning is a relatively new educational model. In 2012, approximately $73 \%$ of teachers had heard of this term. In 2014, that number had increased by $23 \%$ to $96 \%$ of teachers according to an online survey conducted by the Flipped Learning Network. is a "pedagogical approach in which direct instruction moves from the group learning space to the individual learning space, and the resulting group space is transformed into a dynamic, interactive learning environment where the educator guides students as they apply concepts and engage creatively in the subject matter" (Flipped Learning Network, 2014). Similarly, a flipped classroom is one that inverts the traditional style of content acquisition and application. In a flipped classroom, students acquire content knowledge outside of class. During class, instructors actively guide students in practicing the application of that knowledge.

According to the Flipped Learning Network (2014), there are Four Pillars of F-L-I-P: 1) flexible environment; 2) learning culture; 3) intentional content; and 4) professional educator. The pillars act as guidelines for teachers to incorporate into their practices. For example, the first pillar, flexible environment, refers to that fact that teachers using this approach should create flexible learning environments to facilitate group study and independent study. This provides students with the ability to choose how and where they study. Further, teachers who flip their classrooms have more flexible timelines, allowing students to work at their own pace.

The second pillar, fostering a learning culture, means shifting a traditional teacher-centered model to a student-centered model. Students become responsible for their own learning and are actively involved in seeking knowledge. Further, in-class time allows the teachers an opportunity to explore topics in greater depth and allows for more one-on-one time with students.

Teachers use 'intentional content' to determine the best content that they need to teach and the type of material students should explore on their own. This allows for in-class time to be maximized, since concepts are prioritized and relevant for students to be engaged and actively involved. During in-class time, teachers are responsible for continuous observation of their students, providing rapid feedback, and assessing their students' work.

Finally, the role of the educator is of utmost importance in a flipped classroom. Educators' roles shift so that they are spending their classroom time observing, assessing and providing feedback to their students rather than lecturing. Those educators who appear to be most successful at flipping their classrooms are those who are reflective, who connect with their students well and are comfortable with 'controlled classroom chaos' (Flipped Learning Network, 2014).

Flipping a classroom appears to have beneficial effects on student engagement and classroom interaction. Two 2012 surveys report increases in student engagement by $80-85 \%$ in flipped classrooms (Sophia survey, FLN survey). Flipping a classroom also appears to have beneficial effects on learning outcomes. In Bergmann and Sam's (2012) book, Flip Your Classroom: Reach Every Student in Every Class Every Day, the authors explain the impact flipping had on their class- 
rooms. The changes included increased student engagement and interaction and increased learning goal attainment particularly amongst the least advanced and most advanced students.

In 2014, the Flipped Learning Network and Sophia Learning distributed a survey to 2,358 educators and found that $71 \%$ of their respondents reported increased student grades after flipping their classrooms (Yarbro, McKnight, Arfstrom, \& McKnight, 2014) reported a case study of a high school math teacher who flipped his classroom. The results were an increased number of students who passed the state mathematics test (from $29.9 \%$ in 2006 to $73.8 \%$ in 2011) and increased ACT composite scores (from 21.2 in 2006 to 24.5 in 2011). Yarboro, Arfstrom, McKnight, and McKnight (2014) report case studies that all suggest flipping one's classroom can lead to increases in learning achievement. First, math teachers in New York flipped their classrooms and the results were increases in the percentages of students passing the Regents Examinations, which is a NY state standardized test. Second, a teacher in MD flipped her AP calculus class and the result was an increase in the percentage of students who scored a 4 or 5 on the AP exam (from $58 \%$ the year before she flipped her classroom to $78 \%$ after she flipped her classroom (Roshan \& Roshan, 2012)).

As with any new teaching method, there are some concerns. Certainly, flipping a classroom will not make an ineffective teacher effective. Issues of access to technology must be taken into consideration (Project Tomorrow, 2014). The quality of the material that is presented outside of class and the time and resources needed to flip a classroom must all be taken into account (McLaughlin et al., 2014).

There is reason to be hopeful that these concerns are declining as is reported in a survey gathered by Speak Up (2014). This survey reported reduced rates of concern about accessibility, resources needed to flip a classroom and professional development from 2012 to 2013. In the end, the initial reports on the effects of Flipped learning are promising. Despite the concerns, Flipped learning introduces a novel approach to create a rich, student centered environment that has the potential to yield positive results.

\section{Online Learning}

The genesis of online learning is distance education (Lim, Morris, \& Kupritz, 2014). An online learning course is defined as having a majority or all of the course content delivered online with limited face-to-face interaction (Picciano \& Seaman, 2009). The popularity of online learning has considerably grown in both post-secondary and K-12 schools between 2012 and 2013, with over six million students reportedly having taken at least one online course (I. E. Allen \& Seaman, $2013)$. Further, it is estimated that by 2019 , half (50\%) of all high school courses will offered online (Stansbury, 2011).

Fully online learning provides a wide range of benefits. According to a study by Picciano, Seaman, Shea, \& Swan (2012), 60-70\% of respondents said that online learning environments offer courses that are not available at their school; meets the needs of specific groups of students; offers advanced or college level courses; permits students who failed a course to retake it (e.g., credit recovery); and reduces scheduling conflicts for students. In addition, online learning has been used to prevent dropout for at-risk students by allowing them to choose their own instructors, thus increasing engagement (Rosen, \& Beck-Hill, 2012). However, there are also concerns surrounding online learning.

Student accountability is one of the concerns surrounding online learning, specifically in regard to consistency of quality, the expertise of the instructor, and the location of where learning takes place (Watson, Murin, Vashaw, Gemin, \& Rapp, 2011). Another criticism is that online learning may not be the best option for everyone (Rovai \& Jordan, 2004). To be effective, teachers need to be prepared to teach online courses (Clark, 2001). As such, there is a concern that teachers are 
prepared and fully dedicated to learning new teaching strategies and teach online courses (Kennedy \& Archambault, 2012). Despite the concerns, in 2002 the National Education Association underscored the potential of online education and created a policy in support for online learning (as cited in Tucker, 2007).

First measured in a report by the Babson Survey Research Group, chief academic officers reported that online learning outcomes were 'the same,' 'somewhat superior,' and 'superior' to face-toface learning (I. E. Allen \& Seaman, 2013), yet has steadily grown in support, from 57\% in 2003 to $68 \%$ in 2010 (I. E. Allen \& Seaman, 2010). Previous meta-analyses, however, reported no significant difference on outcomes for students between the two modes of instruction (Cavanaugh, Gillan, Kromrey, Hess, \& Blomeyer, 2004; Tucker, 2007). More recent meta-analyses found moderate effects for student achievement and student satisfaction in favor of online learning (Shachar \& Neumann, 2003). A meta-analysis conducted by the USDOE found that "students who took all or part of their class online performed better, on average, than those taking the same course through traditional face-to-face instruction" (Stansbury, 2009, p. 1); however, further investigation of the studies used in the meta-analyses reported flaws in the methodology (Ungerleider \& Burns, 2003; M. Allen, Bourhis, Burrell, \& Mabry, 2002). Two meta-analyses that reported limited methodological flaws found positive effects for student achievement using online learning (Cavanaugh, 2001; Machtmes \& Asher, 2000); however, the effect sizes were relatively small.

Interest in online learning has grown exponentially over the past years. With the wide array of benefits of taking online courses, it is safe to assume that we may see an increase in enrollment in the upcoming years. Unfortunately, as noted, numerous studies on the effects of online learning have methodological flaws, affecting both the overall integrity of the studies and the interpretation of the results (e.g., Ungerleider \& Burns, 2003; M. Allen et al., 2002). Further, for the studies that have limited methodological flaws, the effect sizes were relatively small (e.g., Cavanaugh, 2001; Machtmes \& Asher, 2000). Similar to other technological integration, more sound, rigorous research is needed before confirming the efficacy or inefficacy of online learning.

\section{(RQ2) Investments in education technology}

Educational technology, defined broadly as both hardware and software that support educational goals, is not a new approach to teach. In fact, educational technology has been in classrooms in different forms since the 1920s (Cuban, 1986). In the past, educational technology hardware typically referred to a desktop computer. Today, hardware often also includes laptop computers, Chromebooks, iPads or other tablets, smart phones, and smart whiteboards. Educational software used to refer most typically to CD-ROM-based educational games. There are abundant software options that are often Internet or cloud-based. Newer, more abundant, digital educational technology now includes education applications. These applications are constantly updated and new applications are created and put out into the marketplace daily.

The number of investments made towards purchasing digital devices for students has increased dramatically over the past 25 years (Stokes, Price, Russett, \& Debue, 2003) causing rapid growth of the use of technology in K-12 classrooms (Ringstaff \& Kelley, 2002). In 2010, the United States Government spent approximately $\$ 1.3$ trillion dollars on education, with expenditures at the K-12 level accounting for $\$ 625$ billion of that cost (COE, 2011), and K-12 e-learning expenditures accounting for a small fraction of total education spending $(0.5 \%)$. Expenditures in this market, however, continue to increase. In 2013, the United States Government increased their spending on education to $\$ 1.5$ trillion dollars, with expenditures at the K-12 level accounting for $\$ 718$ billion, and K-12 e-learning accounting for a $(0.7 \%)$ of total k-12 education. Further, the market for for-profit education technology companies has significantly increased from previous years (Richards \& Struminger, 2013). According to a report from the Software \& Information 
Industry Association, 122 education technology vendors reported a combined revenue of $\$ 2.4$ billion, which is a $2.7 \%$ increase from 2012 and a 6.4\% increase from 2010 (Richards \& Struminger, 2013).

\section{Digital tools and internet access}

How has this investment in technology and e-learning translated into access in the classroom? According to the most recent report from the National Center for Education Statistics, approximately $97 \%$ of teachers now have one or more computers in the classroom every day (Gray et al., 2010). Also, teachers report having access to the following technological devices, either as needed or in the classroom every day (Table 2).

Table 2: Most commonly used technological devices

\begin{tabular}{|l|c|c|}
\hline \multicolumn{1}{|c|}{ Technological devices } & $\begin{array}{c}\% \text { available as } \\
\text { needed }\end{array}$ & $\begin{array}{c}\% \text { in classroom } \\
\text { every day }\end{array}$ \\
\hline $\begin{array}{l}\text { Liquid Crystal Displays (LCDs)/ Digital Light Pro- } \\
\text { cessing (DLP) projector }\end{array}$ & 36 & 48 \\
\hline Videoconferencing unit & 21 & 1 \\
\hline Interactive whiteboard & 28 & 23 \\
\hline Classroom response system & 22 & 6 \\
\hline Digital camera & 64 & 14 \\
\hline MP3 player/iPod & 18 & 5 \\
\hline Document camera & 22 & 17 \\
\hline Handheld device, such as a Palm OS or a Pocket PC & 8 & 4 \\
\hline
\end{tabular}

Source: Gray et al. (2010)

Internet access in schools has also increased: $93 \%$ of computers in classrooms have Internet access every day, and $96 \%$ of computers or digital devices brought from home for use in the classroom have Internet access every day (Gray et al., 2010). The actual percentage of students who have a digital device that has Internet access while at school may be even higher given that over half of students in grades 6-12 indicate having access to the Internet in the palms of their hands using 3G/4G enabled mobile devices (Project Tomorrow, 2013). Further, the ratio of students-tocomputer has decreased from 11 to 1 to 1.7 to 1 in the classroom every day (Gray et al., 2010).

With this tremendous growth in school information and communication technology infrastructure, one might assume that teachers have increased the amount of instructional time that they incorporate technology in their practice (Stokes et al., 2003). According to the National Center for Education Statistics, teachers report that $40 \%$ of their students use computers "often" during instructional time and 29\% do so 'sometimes' (Gray et al., 2010). By some accounts, the most common ways that teachers are using technology are for administrative purposes, such as word processing (96\%), accessing the Internet (94\%), and for managing student records (80\%) (Gray et al., 2010). A report conducted by Project Tomorrow (2011) found that teachers reported podcast and internet video use in their classrooms increasing by over $50 \%$ in the past two years. Students are using digital devices primarily for learning or practicing basic skills $(69 \%)$ and conducting research $(66 \%)$.

\section{(RQ3) Effectiveness of educational technology}

Numerous studies have been conducted on educational technology, with over twenty major review done within the last three decades (e.g., M. Allen, Mabry, Mattrey, Bourhis, Titsworth, \& Burrell, 2004; Cengiz Gulek \& Demirtas, 2005; Christmann \& Badgett, 2003; Hartley, 1977; C. L. C. Kulik \& Kulik, 1991; J. A. Kulik, 2003; J. A. Kulik, Kulik, \& Bangert-Drowns, 1985; 
Ouyang, 1993; Penuel, 2006; Rakes, Valentine, McGatha, \& Ronau, 2010; Slavin \& Lake, 2008; Slavin, Lake, \& Groff, 2009). Equally as lengthy has been the long standing debate on the effective of educational technology. In 1983, Richard E. Clark argued that "media have no more effect on learning than a grocery truck has on the nutritional value of the produce it brings to market" (Glick, Aviram, \& Greeener, 2011, p. 30). Since the 1980s, over 60 meta-analyses have been conducted on different areas of educational technology, subject matter, grade level, answering different questions. Most of the reviews have reported positive effect of education on a wide variety of subjects, specifically on mathematical gains. However, other meta-analyses report varying strengths of effect sizes. (See Table 3.)

Table 3: Meta-analyses of effectiveness of technology

\begin{tabular}{|c|c|c|c|c|}
\hline Author & Grade & $\begin{array}{c}\text { Number of } \\
\text { Studies }\end{array}$ & Type of Technology & Effect Size \\
\hline $\begin{array}{c}\text { C. L. C. Kulik and } \\
\text { Kulik (1991) }\end{array}$ & K-12 & 18 & $\begin{array}{c}\text { Computer-based } \\
\text { instruction (CBI) }\end{array}$ & +0.25 \\
\hline Becker (1992) & K-8 & 10 & Integrated learning systems & +0.18 \\
\hline Ouyang (1993) & K-6 & 20 & $\begin{array}{c}\text { Computer-assisted } \\
\text { instruction (CAI) }\end{array}$ & +0.16 \\
\hline $\begin{array}{c}\text { Fletcher-Finn and } \\
\text { Gravatt (1995) }\end{array}$ & K-12 & 23 & $\begin{array}{c}\text { Computer-assisted } \\
\text { instruction (CAI) } \\
\text { Computer-assisted } \\
\text { instruction (CAI) }\end{array}$ & +0.12 \\
\hline $\begin{array}{c}\text { Soe, Koki, and Chang } \\
(2000)\end{array}$ & K-12 & 17 & $\begin{array}{c}\text { Computer-assisted } \\
\text { instruction (CAI) }\end{array}$ & +0.19 \\
\hline $\begin{array}{c}\text { Blok, Oostdam, Otter, } \\
\text { \& Overmatt (2002) }\end{array}$ & $\mathrm{K}-3$ & 42 & & \\
\hline
\end{tabular}

Source: Cheung and Slavin (2012)

Studies that focused on specific subjects, such as mathematics and reading, equally share fluctuating effect sizes. Slavin et al. (2008; 2009) amalgamated 76 studies (38 educational technology reviews on elementary schools and 38 reviews in secondary schools) on the effectiveness of technology (CAI) on mathematical gain, and found a modest effect size of +0.19 for elementary schools and a small effect size of +0.10 for secondary schools (Cheung \& Slavin, 2011, p. 4). Rakes et al. (2010) and Li and Ma (2010) conducted meta-analyses observing the effectiveness of technology-based curriculum (e.g., cognitive tutor) and technology tools (e.g., graphing calculators) on mathematical gains, and found modest effects of +0.15 and +0.17 (as cited in Cheung \& Slavin, 2013).

J. A. Kulik (2003) analyzed 27 studies investigate the overall impact of educational technology on reading. Results found an overall effect size of +0.41 for reading programs such as Writing to Read, and an average effect size of +0.43 for reading management programs such as Accelerated Reader. However, Dynarski et al. (2007) and Campuzano, Dynarski, Agodini, and Rall (2009) observed 5 first grade CAI reading programs and 4 fourth grade CAI reading programs, and found that reading effect sizes were near zero, and the overall effect size for first grade was +0.04 and +0.02 for fourth grade. Researchers believe that these inconsistencies are due to a wide range of issues, such as a "lack of a control groups, limited evidence of initial equivalence between the treatment and control group, large pretest differences, or questionable outcome measures" (Cheung \& Slavin, 2011, p. 4). Also, a majority of these meta-analyses included studies that were conducted in a short duration. Lastly, critical descriptive information (e.g., outcome measures and characteristics of individual studies) was left out (e.g. Hartley, 1977). As a result, studies with 
poor methodologies seemed to report much higher effect sizes compared to those with more rigorous methods.

\section{Conclusion/Discussion}

This paper presents an overview of the literature surrounding the rapid transitions that technology integration has made over the years; the amount of resources and funding that has been allocated to immerse school with technology; and the conflicting results presented on effectiveness of using is technology in education. We found a plethora of instructional strategies being used to integrate technology into K-12 classrooms. Also, though there have been large investments made to integrate technology into K-12 classrooms to equip students with the skills needed to prepare for college and a career, the practical use of this investment has not been impressive. Lastly, several meta-analyses showed promising results of effectiveness of technology in the classroom. However, several inherent methodological and study design issues dampen the amount of variance that technology accounts for. Based on both the experimental and quasi-experimental evidence to date, we highlight a couple of conclusions:

- Currently, the reported ratio of students-to-devices has been reduced from 11:1 to 1.7:1.

- Schools with higher ratios of students per device likely reflect limited resources to purchase the hardware, software, and infrastructure for more devices rather than a belief that having multiple students per device is preferable to a 1:1 ratio.

- Some schools and districts have been able to reduce the ratio of devices to students down to $1: 1$, which is often thought to be the best-case scenario.

Also, there is wide spectrum of technology environments that can deliver educational content. Depending on the needs of the students and the resources of the schools/districts, coursework can be provided via:

- $\quad$ Bring Your Own Device (BYOD)

- Blended Learning

- Flipped Learning \& Flipped Classrooms

- Online learning

In the United States, there has been a significant investment made in educational technology. However, the investment seems to be disproportionate.

- In 2010, the United States Government spent approximately \$1.3 trillion dollars on education, with expenditures at the K-12 level accounting for $\$ 625$ billion of that cost, which is only $5 \%$ of the total education spending.

- In 2013, the United States Government increased their spending on education to $\$ 1.5$ trillion dollars, with expenditures at the K-12 level accounting for $\$ 718$ billion, and K-12 elearning accounting for $0.7 \%$ of the total K-12 education.

Although it seems that there has not been much investment for K-12 education, there certainly has been an increase in integration.

- Approximately $97 \%$ of K-12 teachers now have one or more computers in the classroom every day and also have access to additional technological devices.

- The ratio of students-to-computer has decreased from 11 to 1 to 1.7 to 1 in the classroom every day.

- Also, approximately, $93 \%$ of computers in K-12 classrooms have access to the Internet every day.

- Additionally, $96 \%$ of computers or digital devices brought from home for use in the classroom have access to the Internet every day. 
- However, teachers report that $40 \%$ of their students use computers 'often' during instructional time and $29 \%$ do so 'sometimes.'

From these findings, it can be surmised that although access to computers and digital devices and the Internet has increased, the actual use technology in K-12 classrooms remains low. There are several reasons why use of technology in K-12 classrooms may remain low: 1) teachers' lack of computer skills. There is a strong positive association between teachers' computer skills and students' use computers (Becker, Ravitz, \& Wong, 1998); 2) time for teachers to learn to manage and familiarize themselves with computers is another factor that negatively affects students' use computers (Mumtaz, 2000); and 3) resources, such as technical support in the school setting, has also been shown to affect teachers' use of technology in their classrooms (Sandholtz \& Reilly, 2004).

Addressing these issues is the first step to increase technology use in the classroom. Professional workshops can be used to increase teachers' ability to use their computers (Carlson \& Gadio, 2002) and can help teachers familiarize themselves with computers, instead of wasting valuable course time to learn how to use their computers. In an evaluation by SRI International, more than $80 \%$ of teachers who were surveyed reported that their attitudes about teaching using technology improved 'a lot' or 'a great deal' as a result of their participation in a professional workshop.

As for the over-effectiveness of technology, we found more consistent effect sizes for mathematics and mixed effect sizes for reading.

- Numerous studies report that 1:1 computing environments can lead to significantly higher scores on reading and math achievement tests and overall grade point averages.

- Additionally, students in 1:1 computing environments exhibited increased academic achievement, improved engagement, research skills and collaboration skills.

- Computer-assisted instruction (CAI) showed a modest effect $(+0.19)$ on mathematical gains.

- Programs such as Cognitive Tutor showed a modest effect $(+0.15)$ on mathematical gains.

- Technology tools such as graphing calculators showed a modest effect $(+0.17)$ on mathematical gains.

- Reading programs such as Writing to Read showed a modest effect $(+0.41)$ on reading gains.

- Reading management programs such as Accelerated Reader showed a modest effect $(+0.43)$ on reading gains.

- $1^{\text {st }}$ grade CAI reading programs reading programs showed a small effect $(+0.04)$ on reading gains.

- $4^{\text {th }}$ grade CAI reading programs reading programs showed a small effect $(+0.02)$ on reading gains.

According to these findings, education technology seems beneficial. However, several studies have shown no positive trend in outcomes over long periods of time (Cheung \& Slavin, 2011; Christmann \& Badgett, 2003; Liao, 1998). After conducting a large scale meta-analysis, Cheung and Slavin (2013) provide an interesting and thoughtful perspectives as to why previous studies have yielded mixed results. Firstly, they believe that previous meta-analyses selected studies that were marginal in quality, which would inflate effect sizes. Also, they believe that certain studies may have been neglected when calculating effect sizes, simply because these studies could either positively or negatively affect their effect sizes. Secondly, the type of design used in these studies makes a substantial difference on the findings. Cheung and Slavin (2013) point out that quasiexperimental designs have more variance than experimental designs (e.g., Niemiec \& Walberg, 1987). 
However, studies conducted on the most current instructional strategies that are being used to integrate technology into K-12 classrooms show mixed results. For example, meta-analyses conducted on effects online learning found moderate effects for student achievement and student satisfaction in favor of online learning (Shachar \& Neumann, 2003). The USDOE found that "students who took all or part of their class online performed better, on average, than those taking the same course through traditional face-to-face instruction" (Stansbury, 2009, p. 1). Unfortunately, the studies used in the meta-analyses were riddled with methodological flaws, thus results should be interpreted with caution (M. Allen et al., 2002; Ungerleider \& Burns, 2003). Alternatively, evidence of the efficacy of blended learning were promising (Vignare, 2007). Several metaanalyses found that online courses were at least as effective as traditional classrooms (c.f., Russell, 1999; Zhao et al., 2005). A more recent meta-analysis by Means et al. (2009) found promising results. Forty-six studies compared online to face-to-face conditions, yielding sufficient data to produce 51 effect sizes. Eleven of the 51 effect sizes supported the positive effects of blended learning over traditional face-to-face conditions.

As the digital revolution gains momentum, there will be more opportunities to conduct research on the effect of new technological instructional strategies. With the digital revolution changing the quantity and quality of available information, educators are charged with the responsibility of equipping students with the necessary skills to discern between facts and fiction at a young age. By building students' critical thinking skills, students will have the cognitive skills needed to: 1) discern and identify credible information; 2) have the ability to master the Common Core State Standards; and 3) gain the skills in order to be prepared for college and/or a career.

To accomplish these feats, technological tools and instructional strategies offer teachers the ability to transform their teaching, providing students with plethora of benefits, such as more opportunities for 1 to 1 interaction with their teachers, create flexible learning environments to facilitate group study and independent study, provide students with immediate feedback, offer students advanced or college level courses, permit students who failed a course to retake it, reduce scheduling conflicts for students, and even decrease dropout for at-risk students.

Beyond the ambiguity of the findings, there remains substantial support for the acquisition of technology. Further, the use of technological instructional strategies means formations of nontradition classrooms that range from $0 \%$ of proportion of content delivered online 'Traditional Course with no online technology used' to $80+\%$ of proportion of content delivered online 'Online Learning.' While the present paper has the structure of a literature review, our aim is more at providing information on the trends of technology integration; the amount of resources and funding that has been allocated to immerse school with technology; and the most prominent findings on the effectiveness of using is technology in education. Although we know that this is a wide topic that cannot be explored in one manuscript, we feel that a report that highlights technology integration, funding and investment, and effectiveness is needed. Furthermore, one valuable point that can be gleaned from this paper is this: technology cannot provide any assistance, and surely any advantages, if students do not have the tools or the access to technology.

\section{References}

Allen, I. E., \& Seaman, J. (2010). Learning on demand: Online education in the United States, 2009. Sloan Consortium. PO Box 1238, Newburyport, MA 01950.

Allen, I. E., \& Seaman, J. (2013). Changing course: Ten years of tracking online education in the United States. Newburyport, MA: Sloan Consortium.

Allen, M., Bourhis, J., Burrell, N., \& Mabry, E. (2002). Comparing student satisfaction with distance education to traditional classrooms in higher education: A meta-analysis. The American Journal of Distance Education, 16 (2), 83-97. 
Allen, M., Mabry, E., Mattrey, M., Bourhis, J., Titsworth, S., \& Burrell, N. (2004). Evaluating the effectiveness of distance learning: A comparison using meta-analysis. Journal of Communication, 54(3), 402-420.

Ally, M., \& Tsinakos, A. (Eds.). (2014). Increasing access through mobile learning. Vancouver, BC: Commonwealth of Learning Press.

ASCD. (2009). Fulfilling the promise of the common core state standard. Retrieved from: http://www.ascd.org/ASCD/pdf/siteASCD/commoncore/CCSSSummitReport.pdf

Bebell, D. (2005). Technology promoting student excellence: An investigation of the first year of 1:1 computing in New Hampshire middle schools. Boston: Boston College.

Bebell, D., \& Kay, R. (2010). One to one computing: A summary of the quantitative results from the Berkshire wireless learning initiative. The Journal of Technology, Learning and Assessment, 9(2).

Bebell, D., \& O’Dwyer, L. M. (2010). Educational outcomes and research from 1:1 computing settings. Journal of Technology, Learning, and Assessment, 9(1).

Becker, H. J. (1992). Computer-based integrated learning systems in the elementary and middle grades: A critical review and synthesis of evaluation reports. Journal of Educational Computing Research, 8(1), $1-41$.

Becker, H. J., Ravitz, J. L., \& Wong, Y. (1999). Teacher and teacher-directed student use of computers and software. Teaching, Learning, and Computing: 1998 National Survey. Report\# 3.

Bergmann, J., \& Sams, A. (2012). Flip your classroom: Reach every student in every class every day. International Society for Technology in Education.

Blok, H., Oostdam, R., Otter, M. E., \& Overmatt, M. (2002). Computer-assisted instruction in support of beginning reading instruction: A review. Review of Educational Research, 72(1), 101-130.

Burgess, M. L. (2009). Using WebCT as a supplemental tool to enhance critical thinking and engagement among developmental reading students. Journal of College Reading and Learning, 39(2), 9-33.

Campuzano, L., Dynarski, M., Agodini, R., \& Rall, K. (2009). Effectiveness of reading and mathematics software products: Findings from two student cohorts. Washington, DC: Institute of Education Sciences.

Carlson, S., \& Gadio, C. T. (2002). Teacher professional development in the use of technology. Technologies for Education, 118-132.

Cavanaugh, C. S. (2001). The effectiveness of interactive distance education technologies in K-12 learning: A meta-analysis. International Journal of Educational Telecommunications, 7(1), 73-88.

Cavanaugh, C., Gillan, K. J., Kromrey, J., Hess, M., \& Blomeyer, R. (2004). The effects of distance education on K-12 student outcomes: A meta-analysis. Learning Point Associates/North Central Regional Educational Laboratory (NCREL).

Cengiz Gulek, J., \& Demirtas, H. (2005). Learning with technology: The impact of laptop use on student achievement. The Journal of Technology, Learning and Assessment, 3(2).

Cheung, A. C., \& Slavin, R. E. (2011). The effectiveness of education technology for enhancing reading achievement: A meta-analysis. Center for Research and Reform in Education.

Cheung, A. C., \& Slavin, R. E. (2012). How features of educational technology applications affect student reading outcomes: A meta-analysis. Educational Research Review, 7(3), 198-215.

Cheung, A. C., \& Slavin, R. E. (2013). The effectiveness of educational technology applications for enhancing mathematics achievement in K-12 classrooms: A meta-analysis. Educational Research Review, 9, 88-113.

Christmann, E. P., \& Badgett, J. L. (2003). A meta-analytic comparison of the effects of computer-assisted instruction on elementary students' academic achievement. Information Technology in Childhood Education Annual, 2003(1), 91-104. 
Clark, J. (2001). Stimulating collaboration and discussion in online learning environments. Internet and Higher Education, 4, 119-124.

COE. (2011). Unleashing the potential of educational technology. Retrieved from http://www.whitehouse.gov/sites/default/files/unleashing the potential_of_educationnal_technology.p $\underline{\mathrm{df}}$

Cuban, L. (1986). Teachers and machines: The classroom use of technology since 1920. New York, NY: Teachers College Press.

Cuban, L. (1993). Computers meet classroom: Classroom wins. The Teachers College Record. 95(2), 185210.

Dynarski, M., Agodini, R., Heaviside, S. N., Carey, N., Campuzano, L., Means, B., ... Sussex, W. (2007). Effectiveness of reading and mathematics software products: Findings from the first student cohort. Washington, DC: Institute of Education Sciences.

Fletcher-Finn, C., \& Gravatt, B. (1995). The efficacy of computer-assisted instruction (CAI): A metaanalysis. Journal of Educational Computing Research, 12(3), 219-241.

Flick, L., \& Bell, R. (2000). Preparing tomorrow's science teachers to use technology: Guidelines for science educators. Contemporary Issues in Technology and Teacher Education, 1(1), 39-60.

Flipped Learning Network (FLN). (2014). The four pillars of FLIP ${ }^{\mathrm{TM}}$. Retrieved from http://www.flippedlearning.org/definition

Fulton, K. (2012). Upside down and inside out: Flip your classroom to improve student learning. Learning \& Leading with Technology, 39(8), 12-17.

Glick, D., Aviram, A., \& Greeener, S. (2011). The relationship between mindful learning processes and course outcomes in web-based learning. In Proceedings of the 10th European conference on e-learning (ECEL 2011) (pp. 295-302).

Gray, L., Thomas, N., \& Lewis, L. (2010). Teachers' use of educational technology in US public schools: 2009. First look. NCES 2010-040. National Center for Education Statistics, Institute of Education Sciences, US Department of Education, Washington, DC.

Hartley, S. S. (1977). Meta-analysis of the effects of individually paced instruction in mathematics. University of Colorado at Boulder.

Hew, K. F., \& Brush, T. (2007). Integrating technology into K-12 teaching and learning: Current knowledge gaps and recommendations for future research. Educational Technology Research and Development, 55(3), 223-252.

Hopson, M. H., Simms, R. L., \& Knezek, G. A. (2001). Using a technology-enriched environment to improve higher-order thinking skills. Journal of Research on Technology in Education, 34(2), 109-119.

Information Capsule Research Services. (2014). Bring your own device technology programs: National survey results. Retrieved from http://drs.dadeschools.net/InformationCapsules/IC1308.pdf

Islam, K. (2002). Is e-learning floundering? E-learning, 3(5), 22-26.

Jonassen, D. H. (2000). Computers as mindtools for schools: Engaging critical thinking. Columbus, $\mathrm{OH}$ : Prentice Hall.

Kennedy, K., \& Archambault, L. (2012). Offering preservice teachers field experiences in K-12 online learning: A national survey of teacher education programs. Journal of Teacher Education, 63(3), 185200.

Kulik, C. L. C., \& Kulik, J. A. (1991). Effectiveness of computer-based instruction: An updated analysis. Computers in human behavior, 7(1), 75-94.

Kulik, J. A. (2003). Effects of using instructional technology in elementary and secondary schools: What controlled evaluation studies say. Arlington, VA: SRI International. 
Kulik, J. A., Kulik, C. L. C., \& Bangert-Drowns, R. L. (1985). Effectiveness of computer-based education in elementary schools. Computers in Human Behavior, 1(1), 59-74.

Li, Q., \& Ma, X. (2010). A meta-analysis of the effects of computer technology on school students' mathematics learning. Educational Psychology Review,22(3), 215-243.

Liao, Y. K. (1999). Effects of hypermedia on students' achievement: A meta-analysis. Journal of Educational Multimedia and Hypermedia, 8(3), 255-277.

Lim, D. H., Morris, M. L., \& Kupritz, V. W. (2014). Online vs. blended learning: Differences in instructional outcomes and learner satisfaction. Journal of Asynchronous Learning Networks, 11.

Machtmes, K., \& Asher, J. W. (2000). A meta-analysis of the effectiveness of telecourses in distance education. American Journal of Distance Education, 14(1), 27-46.

Madden, M. (2013). Technology use by different income groups. Pew Research Center. Retrieved from http://www.pewinternet.org/2013/05/29/technology-use-by-different-income-groups/

McGee, P., \& Reis, A. (2012). Blended Course Design: A Synthesis of Best Practices. Journal of Asynchronous Learning Networks, 16(4), 7-22.

McKnight, K, O'Malley, K., Ruzic, R., Franey, J., Kelly, M., \& Bassett, K. (in press). Teaching in a digital age: how educators use technology to improve student learning. Manuscript submitted to Educational Technology Research \& Development.

McLaughlin, J. C., Roth, M. T., Glatt, D. M., Gharkholonarehu, N., Davidson, C. A., Griffin, L. M., ... Mumper, R. J. (2014). The flipped classroom: A course redesign to foster learning and engagement in a health professions school. Academic Medicine, 89, 1-8.

Means, B., Toyama, Y., Murphy, R., Bakia, M., \& Jones, K. (2009). Evaluation of evidence-based practices in online learning: A meta-analysis and review of online learning studies. US Department of Education.

Moeller, B., \& Reitzes, T. (2011). Integrating technology with student-centered learning. A report to the Nellie Mae Education Foundation. Education Development Center, Inc.

Morin, D., Thomas, J. D., \& Saadé, R. F. (2012). Activities and resources in online learning: From a critical thinking view. Proceedings of Informing Science \& IT Education Conference (InSITE) 2012, Montreal, Canada, 597-602. Retrieved from http://proceedings.informingscience.org/InSITE2012/InSITE12p597-602Morin0149.pdf

Muir-Herzig, R. G. (2004). Technology and its impact in the classroom. Computers \& Education, 42(2), 111-131.

Mumtaz, S. (2000). Factors affecting teachers' use of information and communications technology: a review of the literature. Journal of information technology for teacher education, 9(3), 319-342.

Niemiec, R., \& Walberg, H. J. (1987). Comparative effects of computer-assisted instruction: A synthesis of reviews. Journal of Educational Computing Research, 3(1), 19-37.

Norris, C., Sullivan, T., Poirot, J., \& Soloway, E. (2003). No access, no use, no impact: Snapshot surveys of educational technology in K-12. Journal of Research on Technology in Education, 36(1).

ODEP. (2009). Essential skills to getting a job. Retrieved from http://promotions.usa.gov/odep/essential job_skills.pdf

Ouyang, R. (1993). A meta-analysis: effectiveness of computer-assisted instruction at the level of elementary education (k--6).

Pearson. (2013). Pearson student mobile device survey 2013, National report: Students in Grades 4-12. Retrieved from http://www.pearsoned.com/wp-content/uploads/Pearson-Student-Mobile-DeviceSurvey-2013-National-Report-on-Grades-4-to-12-public-release.pdf

Penuel, W. R. (2006). Implementation and effects of one-to-one computing initiatives: A research synthesis. Journal of Research on Technology in Education, 38(3), 329-348. 
Picciano, A. G., \& Seaman, J. (2009). K-12 online learning. The Sloan Consortium.

Picciano, A. G., Seaman, J., Shea, P., \& Swan, K. (2012). Examining the extent and nature of online learning in American K-12 education: The research initiatives of the Alfred P. Sloan Foundation. The internet and higher education,15(2), 127-135.

Project Tomorrow. (2011). The new 3 E's of education: Enabled, Engaged, Empowered. Retrieved from http://www.tomorrow.org/speakup/pdfs/SU10_3EofEducation_Educators.pdf

Project Tomorrow. (2014). The new digital learning playbook: Understanding the spectrum of students' activities and aspirations. Retrieved from http://www.tomorrow.org/speakup/pdfs/SU13StudentsReport.pdf.

Rakes, C. R., Valentine, J. C., McGatha, M. B., \& Ronau, R. N. (2010). Methods of Instructional Improvement in Algebra A Systematic Review and Meta-Analysis. Review of Educational Research, 80(3), 372-400.

Richards, J., \& Struminger, R. (2013). US education technology industry market: PreK-12. Software \& Information Industry Association, Washington, DC.

Ringstaff, C., \& Kelley, L. (2002). The learning return on our educational technology investment. San Francisco, CA: WestEd.

Rosen, Y., \& Beck-Hill, D. (2012). Intertwining digital content and a one-to-one laptop environment in teaching and learning: Lessons from the time to know program. Journal of Research on Technology in Education, 44(3), 225-241.

Roshan, S., \& Roshan, W. (2012, Aug 24). My view: It's never too late to begin flipping your classroom. [CNN's schools of thought blog]. Retrieved from http://schoolsofthought.blogs.cnn.com/2012/08/24/my-view-its-never-too-late-to-begin-flipping-yourclassroom/

Rovai, A. P., \& Jordan, H. (2004). Blended learning and sense of community: A comparative analysis with traditional and fully online graduate courses. The International Review of Research in Open and Distributed Learning, 5(2).

Russell, T. L. (1999). The no significant difference phenomenon. Chapel Hill, NC: Office of Instructional Telecommunications, North Carolina State University.

Saadé, R. G., Morin, D., \& Thomas, J. D. (2012). Critical thinking in e-learning environments. Computers in Human Behavior, 28(5), 1608-1617.

Sams, A., \& Bergmann, J. (2012). Flip your classroom: Reach every student in every class every day. International Society for Technology in Education (ISTE).

Sandholtz, J., \& Reilly, B. (2004). Teachers, not technicians: Rethinking technical expectations for teachers. The Teachers College Record, 106(3), 487-512.

Shachar, M., \& Neumann, Y. (2003). Differences between traditional and distance education academic performances: A meta-analytic approach. The International Review of Research in Open and Distance Learning, 4(2).

Singh, H., \& Reed, C. (2001). A white paper: Achieving success with blended learning. Centra Software.

Slavin, R. E., \& Lake, C. (2008). Effective programs in elementary mathematics: A best-evidence synthesis. Review of Educational Research,78(3), 427-515.

Slavin, R. E., Lake, C., \& Groff, C. (2009). Effective programs in middle and high school mathematics: A best-evidence synthesis. Review of Educational Research.

Soe, K., Koki, S., \& Chang, J. M. (2000). Effect of Computer-Assisted Instruction (CAI) on Reading Achievement: A Meta-Analysis.

Speak Up. (2014). Speak Up 2013 National Research Project Findings A second year review of flipped learning. Retrieved from http://www.tomorrow.org/speakup/2014_FlippedLearningReportTEXT.html 
Stansbury, M. (2009). ED: Blended learning helps boost achievement. eSchool News.

Stokes, D., Price, B., Russett, J., \& Debuke, I. O. (2003). Integrating technology into teaching: A new paradigm shift? Technology and Teacher Education Annual, 2, 1108-1111.

Tucker, B. (2007). Laboratories of reform: Virtual high schools and innovation in public education. Education Sector Reports, 1-19.

Ungerleider, C., \& Burns, T. (2003). A State of the Field Report to the Council of Ministers of Education, Canada and Industry Canada. A systematic review of the effectiveness and efficiency of networked ICT in education. Vancouver. Retrieved from http://www.cmec.ca/stats/SystematicReview2003.en.pdf

Vignare, K. (2007). Review of literature, blended learning: Using ALN to change the classroom - will it work? In A. G. Picciano, \& C.D. Dziuban (Eds.), Blended learning: Research perspectives (pp. 37-63). Needham, MA: Sloan Center for Online Education.

Watson, J., Murin, A., Vashaw, L., Gemin, B., \& Rapp, C. (2011). Keeping Pace with K-12 Online Learning: An Annual Review of Policy and Practice, 2011. Evergreen Education Group.

Yarbro, J., Arfstrom, K. M., McKnight, K., \& McKnight, P. (2014). Extension of a review of flipped learning. Flipped Learning Network, Pearson, \& George Mason University.

Zhao, Y., Lei, J., Yan, B., Lai, C., \& Tan, S. (2005). What makes the difference? A practical analysis of research on the effectiveness of distance education. The Teachers College Record, 107(8), 1836-1884.

\section{Biographies}

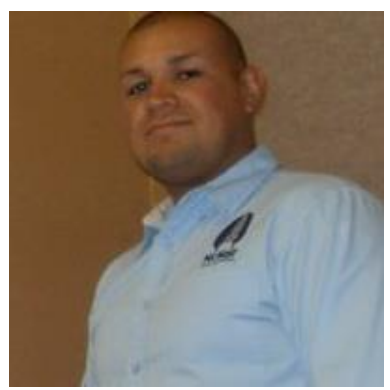

Adolph J. Delgado is a research consultant for Pearson's Research \& Innovations group. Adolph has worked with Pearson since 2012, focusing primarily on understanding and evaluating the current research on the effectiveness of digitally immersed classrooms. His focal responsibilities are amalgamating peer-reviewed literature on technology in the classroom and reporting the most common practices and barriers affecting student outcomes. Further, Adolph serves as a guide on other research studies, providing advice, input, and edits on topics, such as rapid feedback, brain science, and learning theory. Adolph earned his B.A. in Psychology and an M.S. in Health and Kinesiology, focusing on clinical health psychology, health disparities, and program planning and evaluation, with an emphasis on quantitative methods from the University of Texas at San Antonio. He is a lecturer at the University of Texas at San Antonio, where he teaches data management and statistics. He also tutors and facilitates workshops on statistics, research methods, and psychometrics for the McNair Scholars Program and P-20 initiatives. Adolph has presented at numerous scientific conferences, such as the Association for Psychological Science and has submitted 2 publications in peer-reviewed journals. His primary focus is on learning theory and brain plasticity, with an emphasis on the behavioral and neurological deficits of stress and depression.

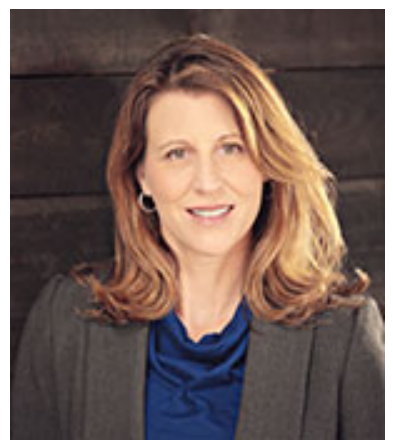

Liane Wardlow, research scientist, focuses on designing and implementing research studies examining e-learning in on-ground and online K-20 classrooms. She also works collaboratively across research centers on a multi-state research project measuring the use and effects of digital technology on teachers' instructional practices and students' learning outcomes. Prior to joining Pearson, Dr. Wardlow worked as a research scientist at the University of CA, San Diego in the Department of Psychology, and for the US Department of Education in the 
Institute for Education Sciences. Dr. Wardlow holds a master's degree in Education from the University of Southern California and a doctorate in Experimental Psychology from the University of CA, San Diego. - See more at: http://researchnetwork.pearson.com/author/lwardlow\#sthash.fpQ5MSmO.dpuf

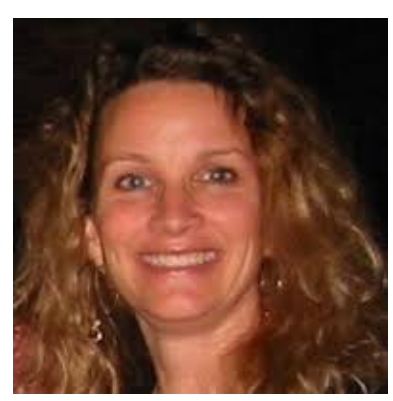

Katherine McKnight leads the Center for Educator Learning \& Effectiveness. She oversees the research agenda for the Center, designs and implements research studies, collaborates with a wide range of education organizations, and shares research results via publications, presentations and social media. With Pearson since 2006, she has directed research and evaluations, focusing on whole school reform and educator effectiveness. Dr. McKnight's current projects focus on educator evaluation systems and career pathways; integration of technology for learning; and collaborative processes for enhancing instruction and learning opportunities for students. She also teaches statistics as an Adjunct Assistant Professor at George Mason University and has developed online statistics courses to train program evaluators. She holds a doctorate degree in Clinical Psychology with an emphasis on Quantitative Methods from the University of Arizona. Follow@McKni8 - See more at: http://researchnetwork.pearson.com/author/kathymcknight\#sthash.dFbx9TP5.dpuf

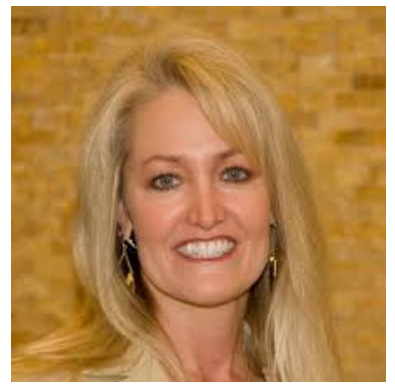

Kimberly O'Malley brings over 10 years of assessment experience to her current role as Pearson's Senior Vice President for Research and Development. Prior to joining Pearson in 2003 as a psychometrician, she was director of the Measurement Excellence Initiative, which provided psychometric analysis and consultation services for various constituents of the United States Department of Veterans Affairs Department of Medicine. She served as assistant professor of Medicine at Baylor College of Medicine, and taught for eight years in elementary and middle school grades with experience in general and special education settings. Dr. O'Malley's research expertise is in topics such as student growth models, which measure focus on the performance of individual students; new applications of standardsetting methods; measurement for English Learners; and transitioning assessment systems. - See more at: http://researchnetwork.pearson.com/author/kimberlyomalley\#sthash.ZmWMr5UK.dpuf 